\title{
Does Students' Financial Behaviour Differ Based on Their Family Income?
}

\author{
Doc. PhD. Dorjana NANO \\ Lecturer University "Eqrem Cabej" \\ nano.dori@yahoo.com
}

PhD. Teuta LLUKANI

Lecturer University "Eqrem Cabej”

t. llukani@gmail.com

\begin{abstract}
This study investigates the differences on Financial Behaviour among Albanian university students based on their family income. The main objectives of this study are: i) firstly, to assess the level of financial behaviour of Albanian university students; ii) to examine whether the financial behaviour differs based on the level of students family income; and ii) finally, , to provide some conclusions and policy implications with regard to financial behaviour. An instrument comprised of specific and personal questions is administered to 637 students from five public and two private universities in Albania. Factor analysing and Cronbach Alpha test are utilized to assess the validity and reliability of the questionnaire. Data analysis is conducted based on the One Way Welch Anova technique. The outcomes discover that Albanian university students show almost a good financial behaviour which differs based on household income. Students with low or middle family income are revealed to show better financial behaviour in comparison with those who reported to have high level of family income. This study paves the way for future research in Albania and for taking incentives for helping students to shape healthy spending habits.
\end{abstract}

Keywords: financial behaviour, family income, Albanian university students.

\section{Introduction}

Students' management skills and behavior has been an issue of concern for about decades. The implication of poor financial management can influence more than students' finances. It can affect their academic performance, mental and physical well-being, and even their ability to find employment after graduation" (Cude, et al. 2006). What is more, students represent a productive market for financial institutions, both as a source of immediate revenue and as a way to promote brand-loyalty through adulthood. The financial decisions made early in life create habits difficult to break which affect students' ability to become financially secure adults (Martin \& Oliva, 2001). A lot of researchers, academics and practitioners studied student's financial behavior and warned unhealthy financial behavior. A healthy financial behavior include: "regular generation of financial statements; budgeting; control of spending; recording income and expenses; and tax, insurance, investment, retirement and estate planning", (Musk \& Winter, 1998 (p. 1). One of the factors found to affect student's financial behavior is their disposal income. Shim and Siegel (1991), in their textbook on the theory and problems of personal finance, highlighted the importance of behavior as an essential ingredient for financial success: "Even with a moderate level of income, you can build substantial wealth by exercising discipline in your financial affairs" (p. 1). Heck (1984) investigated the determinants of financial management behavior of undergraduate students by conducting a survey among 877 participants enrolled in three institutions of higher education in the central New York state region. She found that students who perceived their incomes to be inadequate were less likely to engage in planning behaviors, whereas those who reported higher income were apt to display some implementing behaviors. Implementing behaviors were also found to be discoursed by students who depended financially on their parents and perceived their income as inadequate for meeting their needs. Today's university students have more money to spend than students in past generations, but conversely they have been shown to have low levels of financial literacy and to be impulsive buyers (Hira \& Brinkman 1992; Danes, Huddleston, \& Boyce, 1999; Henry, Weber \& Yarbrough, 2001). Furthermore, studies have revealed that students who report high parental income are more prone to spending money, less interested in financial matters and see less need for 
precautionary saving. These results leads to the following question: Does family income affects students' financial behavior in Albania?

Aims and hypothesis:

The purpose of this research is to investigate whether there is any discrepancy in students' financial behavior based on their family income. The main objectives of this study are:
$\checkmark \quad$ Firstly, to assess the level of students' financial behavior based on different classes of family income;
$\checkmark \quad$ Secondly, to examine whether students' financial behavior differs based on their family income;
$\checkmark \quad$ Finally, to draw some conclusions and policy implications in order to help students in Albania to shape
healthy financial habits.

This research raises the following hypothesis:

\section{Hypothesis: Students with high level of family income display poorer financial behavior compared to students with low or middle level of family income.}

\section{Research Methodology}

This study utilizes a survey focusing on university students. The content of the survey is designed on two parts. The first part comprises personal questions like: gender, age, family income, work experience, etc. The second one consists of two questions testing on how saving or spending oriented students are, and another one considering 8 statements testing budgeting; control of spending; tracking income and expenses; considering several alternatives when making a financial decision; considering risk; paying bills on time and successfully carrying out a spending plan. Participants are asked to rate items using a scale of 1-5 (1-not at all true of me, to 5-very true of me). Data are collected using a stratified sampling method at five public and two private universities across Albania. Public universities involved in this research are: University of Tirana; Agriculture University of Tirana; University "Aleksandër Moisiu", Durrës; University "Aleksandër Xhuvani", Elbasan and University "Eqrem Çabej", Gjirokastër. Private universities considered are: University "Marlin Barleti", Tiranë and "Kristal" University, branch Përmet. A group administered technique is used as the data collection method. The response rate counts for $95 \%$ (607 of 637). Questionnaires completed less than $95 \%$ of the questions involved, are considered unavailable.

The data reported in this study are part of a doctorial study on financial literacy of university students. Data are processed in the Statistical Package for the Social Sciences (SPSS 20). Different techniques are utilized to analyze the data. Hence, factor analyses and the reliability analysis are being useful to test the consistency of the questionnaire. In addition, financial behavior is evaluated as the mean value of the statements' responses that resulted successful from the factor analyses. Furthermore, the one way Welch ANOVA technique is utilized for investigating the differences in financial behavior based on students' family income. Finally, multiple comparisons between different groups, classified according family income classes, are examined by considering Tukey post-hoc test.

\section{Data Analyzing and Findings}

\section{- $\quad$ The consistency of the questionnaire}

The consistency of the questionnaire is tested based on the value of factor loading yielded by the factor analyses of each component included in the financial behavior section, while the reliability is measured based on the Cronbach's Alpha index provided by the reliability analysis. The high proportion of variance in our variables tested by Kaiser-Meyer - Olkin's test $(K M O=\mathbf{0 . 8 0 2})$ indicates a valuable factor analysis. The usefulness of factor analysis is also confirmed by the zero value (less than 0. 05) of the significance level of Bartlett's Test of Sphericity. Two out of ten components included in the factor analyses are extracted based on the Principal Component Analysis, since they loaded less than 0.4 (Table 1). The other factors loaded resulted greater then 0.4 , showing a good internal consistency of the survey. Meanwhile, the Cronbach's Alpha index accounted for 0.717 considering all the items which resulted successfully from the factor analyses. A reliability coefficient of 0.70 or higher is considered "acceptable" as recommended by Cavana et al. , (2001). 
Table 1: Factor \& Reliability Analysis

\begin{tabular}{|c|c|c|}
\hline & Factor Loading & \multirow{5}{*}{$\mathrm{KMO}=0.802$} \\
\hline Planning and tracking spending & 0.710 & \\
\hline Compare prices before shopping & 0.590 & \\
\hline Read to improve my financial knowledge & 0.450 & \\
\hline Pay my bills on time & 0.567 & \\
\hline Before I can buy a product, I consider if I can afford it & 0.618 & \multirow{2}{*}{$\begin{array}{l}\text { Bartlett's Test of } \\
\text { Sphericity Sig. } 000\end{array}$} \\
\hline $\begin{array}{l}\text { How do you classify yourself: Spending oriented or Saving } \\
\text { oriented? }\end{array}$ & 0.605 & \\
\hline How do you usually manage your daily income? & 0.602 & $\begin{array}{l}\text { Cronbach's Alpha index: } \\
0.717\end{array}$ \\
\hline
\end{tabular}

- $\quad$ Sample Characteristics

The profile of 607 respondents who participated in this research is diagrammed in table below. Most of the respondents were males $(71 \%)$, aged $18-22$ years old. Almost half of the respondents (48. 1\%) have reported middle or lower middle family income (greater than 20,000 Lekë - 60,000 Lekë). 36. 6\% declared upper middle or high family income (greater than $60,000-80,000$ Lekë, or greater than 80,000 Lekë), and only $10.6 \%$ displayed low parental income (0 - 20,000Lekë).

\section{Table 2: Sample Characteristics}

\begin{tabular}{|l|l|l|}
\hline Gender & Frequency & Percentage \\
\hline Female & 176 & $29 \%$ \\
\hline Male & 431 & $71 \%$ \\
\hline Total & 607 & $100 \%$ \\
\hline Years of Age & & \\
\hline $18-22$ & 439 & $72.3 \%$ \\
\hline $23-29$ & 126 & $20.8 \%$ \\
\hline $30-39$ & 37 & $6.1 \%$ \\
\hline 39 and over & 4 & $0.7 \%$ \\
\hline Missing system & 1 & $0.1 \%$ \\
\hline Total & 606 & $99.9 \%$ \\
\hline Family Income & & \\
\hline $0-20,000$ Lekë & 64 & $10.6 \%$ \\
\hline Greater than 20,000-40,000 Lekë & 152 & $25.0 \%$ \\
\hline
\end{tabular}




\begin{tabular}{|l|l|l|}
\hline Greater than 40,000 - 60,000 Lekë & 140 & $23.1 \%$ \\
\hline Greater than $60,000-80,000$ Lekë & 121 & $19.9 \%$ \\
\hline Greater than 80,000 Lekë & 106 & $16.8 \%$ \\
\hline Missing system & 24 & $4.6 \%$ \\
\hline Total & 607 & $100 \%$ \\
\hline
\end{tabular}

\section{- Students Financial Behavior}

In order to identify the level of financial behavior and its variation among students with different household income, an analysis of variance (ANOVA) and descriptive statistics are conducted. The distribution of the financial behavior scores is examined separately for each group. Table 3 below displays statistics including the mean, standard deviation, skewness and curtosis of different groups of students. The skewness and curtosis of all categories, except the "low income" group, are shown to be close enough to zero. Even though the values of skewness and curtosis for the first group $(0-20,000$ Lekë) are greater than 1 , their value fall within the interval $\{-2 S D ;+2 S D\}$, showing the distribution to be viewed as normal (Tabachnick \& Fidell, 2000).

Table 3: ANOVA and Descriptive Statistics

\begin{tabular}{|l|l|l|l|l|}
\hline & Mean & $\begin{array}{l}\text { Standard } \\
\text { Deviation }\end{array}$ & Skewness & Curtosis \\
\hline $0-20,000$ Lekë & 3.70 & 0.908 & -1.129 & 1.016 \\
\hline Greater than 20,000-40,000 Lekë & 3.59 & 0.929 & -0.751 & -0.106 \\
\hline Greater than 40,000-60,000 Lekë & 3.70 & 0.854 & -0.809 & 0.107 \\
\hline Greater than 60,000-80,000 Lekë & 3.57 & 0.866 & -0.556 & 0.082 \\
\hline Greater than 80,000 Lekë & 3.48 & 0.918 & -0.539 & -0.087 \\
\hline Differences between groups & $\mathrm{F}=4.073$ & \multicolumn{3}{|c|}{ Sig. $\mathbf{0 . 0 0 3}$} \\
\hline
\end{tabular}

Results of the financial behavior scores accounted for more than 3 showing a good financial behavior. Anyway, this evidence does not prove that Albanian students proactively manage their money, since the upper limit of the financial behavior value is 5 . The overall result of Fisher test $(F=4.073$, sig. $=0.003)$ emerges a statistically significant difference in the overall score of financial behavior among different groups. In closer inspection of the data, it can be observed that students who reported low or middle income yielded the highest score $(M=3.7)$ in financial behavior in comparison with students with other levels of parental income. Students who declare the highest level of parental income (greater than 80,000 Lekë) are shown to perform worse in financial behavior $(M=3.48)$. The Tukey Post Hoc test (table 4) demonstrates the multiple comparisons of the financial behavior mean based on family income. Results revealed a statistically significant discrepancy in financial behavior scores among students with low or middle family income and those with high family income. This outcome approves the hypothesis that students with high level of family income display poorer financial behavior compared to students with low or middle level of family income. 
Table 4: Tukey Post Hoc

\begin{tabular}{|c|c|c|c|c|c|c|}
\hline \multirow[t]{2}{*}{$\begin{array}{l}\text { (I) Family } \\
\text { Income }\end{array}$} & \multirow[t]{2}{*}{ (J) Family Income } & \multirow{2}{*}{$\begin{array}{l}\text { Mean } \\
\text { Differe } \\
\text { nce (I- } \\
\text { J) }\end{array}$} & \multirow[t]{2}{*}{$\begin{array}{l}\text { Std. } \\
\text { Error }\end{array}$} & \multirow[t]{2}{*}{ Sig. } & \multicolumn{2}{|c|}{$\begin{array}{l}\text { 95\% Confidence } \\
\text { Interval }\end{array}$} \\
\hline & & & & & 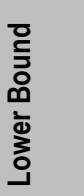 &  \\
\hline \multirow[t]{4}{*}{$\begin{array}{l}0-20,000 \\
\text { Leke }\end{array}$} & Greater than $20,000-40,000$ Lekë & 0.103 & .069 & $\begin{array}{l}0 . \\
565\end{array}$ & -0.08 & 0.29 \\
\hline & Greater than $40,000-60,000$ Lekë & 0.000 & 070 & $\begin{array}{l}1 . \\
000\end{array}$ & -0.19 & 0.19 \\
\hline & Greater than $60,000-80,000$ Lekë & 0.127 & 071 & $\begin{array}{l}0 . \\
382\end{array}$ & -0.07 & 0.32 \\
\hline & Greater than 80,000 Lekë & $0.216^{*}$ & $\begin{array}{l}0 . \\
074\end{array}$ & $\begin{array}{l}0 . \\
027\end{array}$ & 0.02 & 0.42 \\
\hline \multirow{4}{*}{$\begin{array}{l}\text { Greater than } \\
20,000 \quad- \\
40,000 \text { Lekë }\end{array}$} & $0-20,000$ leke & -0.103 & $\begin{array}{l}0 . \\
069\end{array}$ & $\begin{array}{l}0 . \\
565\end{array}$ & -0.29 & 0.08 \\
\hline & Greater than $40,000-60,000$ Lekë & -0.103 & $\begin{array}{l}0 . \\
054\end{array}$ & $\begin{array}{l}0 . \\
317\end{array}$ & -0.25 & 0.04 \\
\hline & Greater than $60,000-80,000$ Lekë & 0.024 & $\begin{array}{l}0 . \\
056\end{array}$ & $\begin{array}{l}0 . \\
993\end{array}$ & -0.13 & 0.18 \\
\hline & Greater than 80,000 Lekë & 0.113 & $\begin{array}{l}0 . \\
059\end{array}$ & $\begin{array}{l}0 . \\
308\end{array}$ & -0.05 & 0.27 \\
\hline \multirow{4}{*}{$\begin{array}{l}\text { Greater than } \\
40,000 \quad- \\
60,000 \text { Lekë }\end{array}$} & $0-20,000$ leke & 0.000 & $\begin{array}{l}0 . \\
070\end{array}$ & $\begin{array}{l}1 . \\
000\end{array}$ & -0.19 & 0.19 \\
\hline & Greater than $20,000-40,000$ Lekë & 0.103 & $\begin{array}{l}0 . \\
054\end{array}$ & $\begin{array}{l}0 . \\
317\end{array}$ & -0.04 & 0.25 \\
\hline & Greater than $60,000-80,000$ Lekë & 0.127 & $\begin{array}{l}0 . \\
057\end{array}$ & $\begin{array}{l}0 . \\
173\end{array}$ & -0.03 & 0.28 \\
\hline & Greater than 80,000 Lekë & $0.216^{*}$ & $\begin{array}{l}0 . \\
060\end{array}$ & $\begin{array}{l}0 . \\
003\end{array}$ & 0.05 & 0.38 \\
\hline \multirow{3}{*}{$\begin{array}{l}\text { Greater than } \\
60,000 \quad- \\
80,000 \text { Lekë }\end{array}$} & $0-20,000$ leke & -0.127 & $\begin{array}{l}0 . \\
071\end{array}$ & $\begin{array}{l}0 . \\
382\end{array}$ & -0.32 & 0.07 \\
\hline & Greater than $20,000-40,000$ Lekë & -0.024 & $\begin{array}{l}0 . \\
056\end{array}$ & $\begin{array}{l}0 . \\
993\end{array}$ & -0.18 & 0.13 \\
\hline & Greater than $40,000-60,000$ Lekë & -0.127 & $\begin{array}{l}0 . \\
057\end{array}$ & $\begin{array}{l}0 . \\
173\end{array}$ & -0.28 & 0.03 \\
\hline
\end{tabular}




\begin{tabular}{|c|c|c|c|c|c|c|}
\hline & Greater than 80,000 Lekë & 0.089 & $\begin{array}{l}0 . \\
062\end{array}$ & $\begin{array}{l}0 . \\
608\end{array}$ & -0.08 & 0.26 \\
\hline \multirow[t]{4}{*}{$\begin{array}{l}\text { Greater than } \\
80,000 \text { Lekë }\end{array}$} & $0-20,000$ leke & $-0.216^{*}$ & $\begin{array}{l}0 . \\
074\end{array}$ & $\begin{array}{l}0 . \\
027\end{array}$ & -0.42 & -0.02 \\
\hline & Greater than 20,000 - 40,000 Lekë & -0.113 & $\begin{array}{l}0 . \\
059\end{array}$ & $\begin{array}{l}0 . \\
308\end{array}$ & -0.27 & 0.05 \\
\hline & Greater than $40,000-60,000$ Lekë & $-0.216^{*}$ & $\begin{array}{l}0 . \\
060\end{array}$ & $\begin{array}{l}0 . \\
003\end{array}$ & -0.38 & -0.05 \\
\hline & Greater than $60,000-80,000$ Lekë & -0.089 & $\begin{array}{l}0 . \\
062\end{array}$ & $\begin{array}{l}0 . \\
608\end{array}$ & -0.26 & 0.08 \\
\hline
\end{tabular}

\section{Conclusions, Discussions and Recommendations}

This research investigated the financial behavior of 607 students from multiple universities across the country. It revealed the level of financial behavior and its discrepancy among Albanian university students based on their family income. The study showed that Albanian university students display a good financial behavior, but not a smart one. In addition, parental income is revealed to affect student's financial behavior. Evidences suggest that students with high level of family income are more likely to display poorer financial behavior in comparison with students with low or middle ones.

The results of this survey can be mainly explained by the inappropriate parental guidance about money smart. Parents mostly overlook teaching children financial skills like saving and budgeting. Students with higher parental income may have the attitude that money comes easily and they can buy whatever they want, so that they do not need to budget, save or invest. On the other hand, students with low or middle parental income may have had to learn to be careful with their money and need to budget and invest in order to meet their needs. Parents show an example for financial behavior to their children for better, or for worse. They can provide a message that "money is burning a hole in your pocket", or "money matters". Training parents on how to teach children healthy financial habits will help them better to be able to teach and model positive financial habits in the home. It is essential to parents to teach children to set priorities and give them a personal allowance in order to value money. In addition, institutions of higher education, banks and professionals could offer seminars to students on the importance and ways to establish a proactively financial lifestyle.

Based on the findings of the present study it is recommended that further qualitative research be conducted to gain insight in depth of students' financial behavior. In addition, future studies could be undertaken to understand and control for other factors influencing students' financial behavior.

\section{References}

[1] Cavana, R. Y. , Delahaye, B. L. , \& Sekaran, U. , (2001). Applied Business Research: Qualitative and Quantitative Methods. Queensland: John Wiley \& Sons Australia, Ltd.

[2] Cude, J., Frances, C. , Lawrence, Angela, C. , Lyons, A. , Kaci, M. , Lejeune, E. , Marks, L. , Machtmes, K. College Students And Financial Literacy: What They Know and What We Need to Learn. Eastern Family Economics and Resource Management Association. Conference 2006: 102-109.

[3] Danes, S. M. , Huddelston-Casas, C. , \& Boyce, L. (1999). Financial planning curriculum for teens: Impact evaluation. Financial Counseling and Planing, 10 (1), 25-38.

[4] Heck Z. K. R. , (1984). The Determinants of Financial Management Behaviors among College Students: Implications for Consumer Education. The Journal of Consumer Education, 2, 12-17. 
[5] Henry, R. A. , Weber, J. G. \& Yarbrough, D. (2001). Money Management Practices of College Students. College Student Journal, 35 (2), 244-249.

[6] Hira, T. K. \& Brinkman, C. S. (1992) "Factors Influencing the Size of Student Debt," Journal of Student Financial Aid, 22 (2). Available at: http: //publications. nasfaa. org/jsfa/vol22/iss2/3

[7] Martin, A. , \& Oliva, J. C. (2001). Teaching children about money: Applications of social learning and cognitive learning developmental theories. Journal of Family and Consumer Sciences, 93 (2), 26-29.

[8] Musk, G. , \& Winter, M. (1998). Real world financial management tools and practices. Consumer Interests Annual [Online], (44), p1. Available: www. ehostvgw. 8epnet. com [2000, February 10].

[9] Siegel G. Joel and Shim K. Jae, (1991): Finance EZ - 101. Barron's Educational Series, Incorporated.

[10] Tabachnick, B. , \& Fidell, L. , (2000): Using Multivariate Statistics (4th Ed. ). Allyn \& Baceon, Incorporated, Boston. 